Justyna Dworniak

\title{
Zdrowie bez pomocy lekarza, czyli medycyna i wiara pośród angielskich bogatych i biednych w okresie średniowiecza
}

W dobie dzisiejszego postępu mieszkańcy krajów rozwiniętych mają wysokie oczekiwania w odniesieniu do specjalistów oraz instytucji zajmujących się medycyną. Wielkie kroki poczynione w naukach medycznych i pokrewnych dały bogatym ludziom nadzieję, że leki i sama medycyna przywrócą im dobry stan zdrowia i przedłużą życie.

Obecne prace naukowe dotyczące sztuki Hipokratesa w dzisiejszej Anglii opierają się, w dłużej mierze, jeszcze na średniowiecznych woluminach, które nadal stanowią podstawę kształcenia medycznego, mimo znaczącego postępu we współczesnej medycynie. W okresie średniowiecza powstało wiele ksiąg poświęconych ars medica, jednak wśród mieszkańców ówczesnego Albionu panowało przekonanie, że nauka medycyny jest mało potrzebna, wręcz zbędna. Fakt ten wynikał zapewne z tego, iż społeczeństwo angielskie było biedne, a bogaci unikali lekarzy z wyboru. Zarówno członkowie elit, jak i zwykli obywatele średniowiecznej Anglii uważali, że dieta, oszczędne życie i uduchowienie są kluczem do długiego i pozbawionego chorób życia.

Tradycja rzymskiego stoicyzmu opierała się w dużej mierze na dziełach Pliniusza. W średniowiecznej Anglii jego dorobek cieszył się uznaniem. Roger Bacon często cytował dzieło Naturalis historia w swoich pismach dotyczących zdrowia. Zestawiał argumenty starożytnego historyka z Pismem Świętym przypominając, że pierwszym grzechem ludzi było nie tylko nieposłuszeństwo, ale także zakazany owoc ${ }^{1}$. Oprócz Pliniusza, pisarze angielscy odwoływali się także do niektórych porad medycznych Arystotelesa. Powrót do antycznych źródeł i zgłębianie pism starożytnych w celu poznania sposobu na pozbawione chorób życie często jest określane mianem

1 R. Bacon, Epistola de secretis operibus artis et naturae, tłum. B. Orłowski, [w:] Wielcy i mali twórcy cywilizacji, red. L. Sprague De Camp, Warszawa 1968, s. 407. 
medycznego humanizmu². Praktyczne porady, tworzenie w ojczystym języku i otwartość na novum, nawiązywało do tego nurtu, szczególnie w swoich najwcześniejszych formach ${ }^{3}$. Ten szacunek do pism starożytnych Rzymian i chęć ich zgłębiania można zaobserwować już w czasach anglosaskich, kiedy tworzono tłumaczenia tekstów łacińskich, dotyczących późnoantycznej medycyny. Sama wiedza medyczna w ówczesnej Anglii opierała się na zestawach zaklęć, ocalałych teoriach klasycznych i zabobonach (w okresie rozkwitu i późnego średniowiecza wykorzystywano natomiast teorię humorów i astrologii). Najstarsze zachowane teksty poświęcone ars medica napisane w języku staroangielskim pochodzą z IX w. Należą do nich m.in. Leechbook, Leechbook III ${ }^{4}$ Balda i Lacnunga ${ }^{5}$. Pierwszy z nich (Leechbook) jest jednym z najdokładniejszych dzieł poświęconych medycynie śródziemnomorskiej okresu od III do IX w. n.e.

Zastosowanie ziół w medycynie miało duże znaczenie. Chociaż znalezienie odpowiedników ówcześnie występujących roślin w czasach współczesnych jest trudne, to znaczna część tych herbes ma do dnia dzisiejszego zastosowanie w medycynie. W wymienionych tekstach z IX w., obok importowanych roślin, obecne są także rzodkiewki, trybule, koper, czosnek czy szałwia. Co ciekawe, recepta $\mathrm{z}$ Leechbook Balda zawiera przepis na maść na bazie pokrzywy, którą używano na bóle mięśni. Podobny specyfik, mający

2 R. Weiss, Humanism in England during the Fifteenth Century, Oxford 1957, s. 22. Na temat średniowiecznego humanizmu w Anglii vide R. W. Southern, Scholastic Humanism and the Unification of Europe, Oxford 1995, s. 17-57.

3 Ch. G. Nauert, Humanism and the Culture of Renaissance Europe, Cambridge 1995; na temat transmisji tekstów antycznych w literaturze średniowiecznej Anglii vide L. D. Reynolds, N. G. Wilson, Scribes and Scholars: A Guide to the Transmission of Greek and Latin Literature, Oxford 1974; J. M. Levine, Humanism and History: Origins of Modern English Historiography, New York 1987; na temat medycyny vide J. J. Bylebyl, Medicine, Philosophy, and Humanism in Renaissance Italy, [w:] Science and the Arts in the Renaissance, ed. J. W. Shirley, F. D. Hoeniger, Washington 1985, s. $27-49$.

4 Znane także jako Medicinale Anglicum; vide M. L. Cameron, Anglo-Saxon Medicine, [w:] Cambridge Studies in Anglo-Saxon England 7, Cambridge 1993, s. 42; R. N. Scott, The several compilers of Bald's Leechbook, "Anglo-Saxon England" 2004, No. 33, s. 51-76.

5 Inaczej „Remedia”. Lacnunga zawiera wiele unikalnych tekstów, wśród których znajdują się także zaklęcia i uroki. Jednym z najbardziej popularnych zaklęć było „Wið færstice” (przeciw nagłemu i przeszywającemu bólowi), znane jako „zaklęcie dziewięciu ziół” - vide O. Cockayne, Leechdoms, Wortcunning, and Starcraft of Early England, t. 2, London 1864. 
to samo zastosowanie, występuje dzisiaj w sprzedaży. Leechbook III zawiera dużą liczbę medykamentów, które wykonywano wyłącznie przy użyciu rodzimych składników. Nazwy tych roślin nie są podane w zanglicyzowanej łacinie, co dowodzi, że zioła te czerpano w znacznym stopniu z domowych upraw ${ }^{6}$. Oprócz składników śródziemnomorskich lub pochodzących z terenów Brytanii, teksty zawierały także wskazówki dotyczące zastosowania materia medica z odległych zakątków świata (kadzidło, jedwab, imbir, pieprz, mirra).

Jednym z pierwszych dzieł napisanym w duchu medycznego humanizmu był tekst Henry'ego Daniela, w języku angielskim, dotyczący uroskopii, a sporządzony w roku $1379^{7}$. Liber Uricrisiarum ${ }^{8}$ było angielskim opracowaniem De Urinis Isaaca Judaeusa, które zostało także przedstawione po łacinie przez Constantinusa Africanusa ${ }^{9}$. Celem traktatu Daniela było dotarcie do szerszej grupy medyków, ponieważ literatura medyczna i książki były dostępne na uczelniach jedynie dla kształconych tam lekarzy. Ponadto zaznajomienie się z tymi dziełami wymagało opanowania greki i łaciny. Jak pisał sam autor, tworząc swój traktat chciał zachęcić i przekonać czytelników do stosowania medycyny ${ }^{10}$. Tego rodzaju tłumaczenia medyczne nie wzięły się znikąd. Stanowiły część większego ruchu, zmierzającego do upowszechnienia języka narodowego w literaturze angielskiej w drugiej połowie XIV w. ${ }^{11}$

W Anglii humanizm medyczny objawił się nie za sprawą doktora nauk medycznych, a dzięki jednemu z największych angielskich poetów doby

6 M. L. Cameron, Anglo-Saxon Medicine, s. 44.

7 Wstęp do uroskopii Daniela zawiera wiele obszernych notatek oraz materiału wprowadzającego, którego autorem był Ralph Hanna III - vide R. Hanna, Henry Daniel's Liber Uricrisiarum (Excerpt), [w:] Popular and Practical Science of Medieval England, ed. L. M. Matheson, [sl.] 1994, s. 185-218.

8 Uroskopia sama w sobie została napisana po angielsku, ale prolog mówiący o znaczeniu tłumaczenia na języki narodowe jest po łacinie.

9 J. Jasin, A Critical Edition of the Liber Uricrisiarum, New Orleans 1994, s. 9, 12; R. Hanna, Henry Daniel's..., s. 189.

10 D. A. Larusso, Rhetoric in the Italian Renaissance, [w:] Renaissance Eloquence: Studies in the Theory and Practice of Renaissance Rhetoric, ed. J. J. Murphy, Berkeley 1983, s. 37-55; J. J. Murphy, Medieval Rhetoric: A Select Bibliography, Toronto 1989.

11 W. J. Courtenay, From Schools to Court Circles: Scholasticism and Middle English Literature, [w:] Schools and Scholars in Fourteenth-Century England, Princeton 1987, s. 374-380. Courtenay zauważa, że pisanie w języku ojczystym w Anglii było związane z filozoficznymi tendencjami nominalizmu i realizmu. Vide A. G. Rigg, The Latin Verses in the Confessio Amantis: An Annotated Translation, eds. S. Echard, C. Fanger, East Lassing 1991, s. 13-24. 
średniowiecza. Mowa tu o Geoffreyu Chaucerze (zm. w 1400 r.). Jego zainteresowanie medycyną zapewne narodziło się po podróży do Włoch i Francji, które wielokrotnie odwiedził z misją dyplomatyczną w latach siedemdziesiątych XIV w. Prawdopodobnie odwiedził Florencję, gdzie mógł nauczyć się języka włoskiego, korzystając m.in. z prac Boccaccia i Petrar$\mathrm{ki}^{12}$. W swoich dziełach Chaucer odnosił się, oprócz wyżej wymienionych poetów, m.in. także do Owidiusza, Guillaume de Loris czy Dantego. Petrarka napisał Invectiva contra Medicum (Inwektywy przeciw medykom), skierowane do lekarzy towarzyszących papieżowi Klemensowi VI w Awinionie. Pisma Chaucera nie wykazują bezpośredniej znajomości Invectiva, ale jego odczucia korespondują z polemiką prowadzoną u Petrarki (odnośnie do lekarzy papieża, którzy „zanieczyszczają medycynę plugawymi czynami”). W swoim dziele Chaucer wyraża przekonanie o istnieniu czterech płynów ciała (humorów): krwi, żółci, śluzu (flegmy) i czarnej żółci, które wypełniały ciało, a ich wzajemne stosunki wpływały na zdrowie i temperament. Pogląd ten nawiązuje do jednego z głównych nurtów w medycynie starożytnej, zapoczątkowanego przez Hipokratesa ${ }^{13}$. Ówcześni medycy przeanalizowali nadmiar strawionych produktów (kał, mocz, krew menstruacyjna i hemoroidalna oraz pot), aby dowiedzieć się, co dzieje się wewnątrz ciała. Tego typu analiza w czasach współczesnych zyskała miano medycyny dietetycznej, czyli inaczej dietetyki.

W średniowieczu medycyna dietetyczna obejmowała diety w klasycznym znaczeniu słowa dieta, rozumianego jako ogólny tryb życia. Z tego punktu widzenia sposób, w jaki funkcjonowało ciało - jego fizjologia - był uwarunkowany kilkoma czynnikami, które wpływały na samopoczucie. Opisem tych czynników zajął się już Galen (ok. 130-200 n.e.). Były to: żywność, napoje i post; sen i bezsenność; powietrze; ćwiczenia i odpoczynek; wydalanie i wstrzymywanie oraz emocje. Wśród czynników znaleźć można także abstynencję i stosunek seksualny. Umiar w tych kwestiach miał prowadzić do dobrego zdrowia. W teorii dobry medyk wiedział, co zrobić, by za sprawą diety jego pacjent odzyskał zdrowie. Należy pamiętać, że oprócz tego,

12 Na temat podróży Goeffrey’a Chaucera vide The Works of Geoffrey Chaucer, ed. F. N. Robinson, Boston 1957, s. 19-28; na temat jego życia vide Chaucer Life-Records, eds. M. M. Crow, C. C. Olson, London 1966.

13 Hipoteza o wzajemnym wpływie czterech soków była obecna u Hipokratesa, a została spisana przez jego zięcia i ucznia Polibiusza w dziele O naturze człowieka (znanym pod łacińskim tytułem De natura hominis), wchodzącym w skład zbioru Corpus Hippocraticum. 
w średniowieczu ważnym aspektem były także emocje i duchowość, które gwarantowały dobre samopoczucie ${ }^{14}$. Z Opowieści kanterberyjskich ${ }^{15}$ dowiadujemy się, jak fizycy (medycy) praktykowali medycynę. Chaucer mówi o korzystaniu z systemu humorów, astrologii, diagnozy i leczenia swoich pacjentów, a także pokazuje, że istnieje ogromna różnica między chirurgiem a medykiem w tych czasach. Całość „Prologu” jest także dyskursem, który w satyryczny sposób przedstawia medycynę akademicką. Chaucer, ceniony poeta i dworzanin, nie był znawcą praktyk medycznych. Jego wskazówki zawarte w „Prologu”, zostały przekazane tak, aby mogły trafić do szerszej grupy czytelników ${ }^{16}$.

Przekonania Chaucera dotyczące medycyny zdają się odnosić do filozofii stoickiej. Według poety, wszelkie niepowodzenia są przejściowe. Żeby je przetrwać, należy zachować we wszystkim umiar i dietę. Dla Chaucera medycyna była, podobnie jak dla Pliniusza, częścią gospodarstwa domowego, a nie filozofii. Autor Opowieści kanterberyjskich uważał, że umiarkowany styl życia i stoicyzm w obliczu cierpienia, którego doświadcza ciało, ma zapobiegać dalszym chorobom (m.in. zaburzeniom psychicznym).

Problem głodu, epidemie i zwichnięcie społeczne ubogich uniemożliwiało medykom prowadzenie praktyk wśród mieszkańców angielskich miast. Historycy zauważają, że medycyna w tym okresie niewiele mogła zrobić dla chorych. Mimo to, w średniowieczu działały punkty opieki nad bezdomnymi, kalekami, sierotami czy wdowami. Takie miejsca udzielały im schronienia, dokarmiały oraz dawały ochronę i opiekę. Tego typu pomocą w ówczesnej Anglii, podobnie jak i w innych częściach Europy, zajmowały się osoby duchowne. Szpital średniowieczny miał więcej wspólnego z dzisiejszymi hospicjami, hotelami i motelami, niż ze szpitalem w obecnym znaczeniu tego słowa. Najwcześniejsze instytucje charytatywne w Anglii były po prostu domami gościnnymi. Angielska nazwa szpitala (hospital) pochodzi bowiem od słowa hospes, oznaczającego gościa. W przeprowadzonych badaniach nad średniowiecznymi szpitalami Marta Carlin nie znalazła praktycznie żadnych wzmianek na temat opieki medycznej, sprawowanej przez lekarzy i chirurgów. Okazało się natomiast, że „leczenie chorych polegało

14 L. J. Rather, The Six Things Non-Natural: A Note on the Origins and Fate of a Doctrine and a Phrase, "Clio Medica" 1968, No. 3, s. 337-347.

15 L. M. Koff, Chaucer and the Art of Storytelling, California 1988, s. 78; H. Sweet, First Middle English Primer, Pennsylvania 2005.

16 K. Giocarinis, R. Kay, The Medieval Heritage of a Humanistic Ideal: "Scientia Donum Dei Est, unde Vendi Non Potest”, “Traditio” 1955, No. 11, s. 195-234. 
na odpoczynku w łóżku, cieple, czystości i odpowiedniej diecie"17. Instytucje te finansowane były prawie wyłącznie dzięki datkom. W niektórych szpitalach przyjmowano jedynie starszych ${ }^{18}$ albo obłąkanych ${ }^{19}$. Zazwyczaj instytucje te były zarządzane na sposób monastyczny, ze ścisłym przestrzeganiem diety i modlitwy, zwłaszcza za duszę dobroczyńcy ${ }^{20}$. Sam budynek szpitalny (mowa tu o budynkach, znajdujących się przy klasztorach i ufundowanych przez zgromadzenia monastyczne) zaprojektowany był z troską o higienę, tak, aby chory nabierał sił, zarówno fizycznych, jak i duchowych. Jako metody leczenia wykorzystywano upust krwi, ziołowe medykamenty, odpoczynek, odżywczą dietę. Czasami terapia obejmowała także relaks przy muzyce. Prawdopodobnie szpitale zakonne trudniły się poradami medycznymi, a niekiedy także dostarczały leków, ponieważ często przy klasztorach istniały herbaria, czyli ogródki zielne. Kiedy szpitale zaczęły być fundowane przez prywatne osoby, administrowano je w podobny sposób.

Pierwsze szpitale w Anglii zostały założone przez rzymskie wojska. Szpital zbudowany w Perthshire w końcu I w. n.e. mógł mieć więcej niż 250 miejsc $^{21}$. Po odejściu rzymskich najeźdźców nie odnotowano dowodów funkcjonowania tych jednostek ${ }^{22}$. Jak podają źródła, dopiero w X w. (925940) pojawiają się dwa miejsca, które można przyrównać do szpitali lub dzisiejszych hospicjów. Oba znajdowały się w Yorku ${ }^{23}$, jeden poza miastem, a drugi w jego obrębie. Na Flixton w Holderness znajdował się dom schronienia, który miał „na celu chronić podróżnych przed pożarciem przez wilki i inne zwierzęta leśne" ${ }^{24}$. Dwa wczesne domy miłosierdzia przypisane są

17 M. Carlin, Medieval English Hospitals, [w:] The Hospital in History, eds. L. Granshaw, R. Porter, London 1989, s. 31.

18 Na temat prawnych, religijnych i obyczajowych opinii o starości i jak należy ją pojmować vide: S. Shahar, Who Were Old in the Middle Ages, "Social History of Medicine" 1993, No. 6, s. 313-341; na temat opieki nad starszymi poza szpitalami w średniowieczu pisze m.in. E. Clark, Some Aspects of Social Security in Medieval England, "Journal of Family History" 1982, No. 7, s. 307-320.

19 C. Rawcliffe, The Hospitals of Later Medieval London, "Medical History 1" 1984, No. 28, s. 11.

20 Ibidem, s. 11-12. Rawcliffe opisuje schemat modlitwy w jednym ze szpitali w Londynie jako „kierat pobożnej wdzięczności” (s. 12).

21 N. Orme, M. Webster, The English Hospital 1070-1570, New Haven 1995, s. 15.

22 Ibidem, s. 20.

23 Prawdopodobnie istniały także inne saksońskie szpitale. Orme i Webster twierdzą, że według tradycji były to St. Giles’ w Beverley i St. Nicholas' w Pontefract, vide N. Orme, M. Webster, The English Hospital..., s. 57.

24 M. R. Clay, The medieval hospitals of England, London 1909, s. 3. 
biskupom saskim Oswaldowi i Wulstanowi Worcesterowi. Ze źródeł ${ }^{25}$ wiemy, że w XI w. św. Wulstan założył szpital w pobliżu swojego miasta, któremu potem nadano jego imię.

W połowie XII w., już po inwazji normańskiej, istniało prawie siedemdziesiąt takich instytucji. Do XIV w. odnotowano 550 szpitali na terenie Anglii ${ }^{26}$. We wszystkich tych miejscach opiekę nad chorymi sprawowały kobiety, natomiast zarządzaniem zajmowali się mężczyźni ${ }^{27}$. W późniejszym średniowieczu osoby prywatne oraz gildie były coraz bardziej zaangażowane $\mathrm{w}$ fundowanie szpitali i pomoc ubogim. W Yorku Gildia Cordwainers ufundowała Maison Dieu, który został założony przez jednego z jej członków, Johna Martena. Ponadto Maison Dieu, działający w pobliżu Walmgate Bar (data jego powstania nie jest znana, mógł zostać ufundowany w XIV lub XV w.), należał do cechu szewców i świadczył usługi prawdopodobnie jedynie członkom gildii i ich rodzinom. Szpital św. Antoniego w Peaseholm był zależny od gildii św. Antoniego, która była jego fundatorem.

Szpital Savoy w Londynie, finansowany przez Henryka VII w 1512 r., został zbudowany według modelu Santa Maria Nuova we Florencji ${ }^{28}$. Władca zmarł w 1509 r., co znaczy, że jego wolę (odnośnie do samego szpitala) wypełniono dopiero 3 lata po jego śmierci. Było to miejsce przeznaczone dla ubogich i potrzebujących. Henryk zostawił instrukcje dotyczące administrowania szpitalem w swoim testamencie ${ }^{29}$. Budynek w Savoy miał jedną z najbardziej imponujących konstrukcji swoich czasów i jako pierwszy korzystał ze stałego personelu medycznego. Został zamknięty w 1702 r., a w XIX w. rozebrano go.

Kilka zakonów ufundowało swoje szpitale w okresie krucjat: templariusze, joannici, lazaryci z Jerozolimy, a także trynitarze, którzy zajmowali się głównie opieką nad podróżującymi i trędowatymi. Ich liczba nie była zbyt duża. N. Orme i M. Webster znaleźli tylko sześćdziesiąt takich instytucji z około pięciuset w XIII w. Gościnność i niesienie pomocy biednym, pielgrzymom czy podróżnym była tak charakterystyczna dla szpitali założonych

25 I. Bollandus, Acta Sanctorum: Junii I, Antwerp 1695, s. 728-742; D. H. Farmer, The Oxford Dictionary of Saints, Oxford 1978, s. 197; F. T. Marsh, Annals of the Hospital of S. Wulstan, or the commandery in the city of Worcester; together with a chartulary of the said hospital, Worcester 1890, s. 111-114.

26 N. Orme, M. Webster, The English..., s. 35.

27 M. Carlin, Medieval English, s. 32.

28 C. Rawcliffe, The English Hospital..., s. 12.

29 S. Bassett, Death in towns: urban responses to the dying and the dead 100-1600, Leicester 1993, s. 23. 
przez zakonników, że często nazywano te przybytki po prostu hospicjami. Jak pisze Stanley Rubin:

W klasztorach gościnność była obowiązkiem religijnym; dla zakonu joannitów najważniejszym. Zakon ten miał oddziały w całej Anglii, co było szczęściem dla ubogich podróżników. Nie ulega wątpliwości, że odwiedzający byli traktowani według swojego statusu, ale dla każdego kto potrzebował pomocy drzwi stały otworem ${ }^{30}$.

Joannici byli również odpowiedzialni za niektóre szpitale: administrowanie słynnego Szpitala św. Krzyża w Winchester, którego fundatorem był Henryk de Blois w roku 1132 zostało powierzone właśnie temu zakonowi. Jednostka ta była kontrolowana przez joannitów przez następne pół wieku ${ }^{31}$.

Trzeba pamiętać, że głównym celem opieki szpitalnej nie było ratowanie życia, a umożliwienie pobożnym chrześcijanom praktycznej realizacji wezwania do miłości do bliźniego poprzez opiekę nad chorymi i potrzebującymi ${ }^{32}$. Przez całe średniowiecze $w$ Anglii odbywały się pielgrzymki do świętych sanktuariów, w których chorzy mogli doświadczyć uzdrowienia. Canterbury Tales Chaucera są kroniką opowieści z podróży do sanktuarium św. Tomasza Becketa w Canterbury ${ }^{33}$. Mężczyźni i kobiety ze wszystkich warstw społecznych poprzez lekturę tego dzieła mogli uczestniczyć w tej wyimaginowanej podróży. Odzwierciedlało to zapewne potrzebę szukania przez społeczeństwo średniowiecznej Anglii uzdrowienia (fizycznego, psychicznego, duchowego) za sprawą cudu, który miała przynieść wiara ${ }^{34}$. Sanktuaria różnych świętych były i są pełne relikwii, zwłaszcza kości, włosów i innych fragmentów ciała, należących do świętych ${ }^{35}$. Podobnie jak chleb

30 S. Rubin, The Monastic Infirmary, [w:] Medieval English Medicine, New York 1974, s. $172-188$.

31 Na temat samego szpitala vide P. Hopewell, Saint Cross: England's Oldest Almshouse, Chichester 1995.

32 C. Rawcliffe, The English Hospital..., s. 11.

33 The Works of Geoffrey Chaucer, s. 17.

$34 \mathrm{Na}$ temat natury dokonanych cudów vide E. Gordon, Child Health in the Middle Ages as Seen in the Miracles of Five English Saints, A.D. 1150-1220, "Bulletin of the History of Medicine" 1986, No. 60, s. 502-522; idem, Accidents among Medieval Children as Seen from the Miracles of Six English Saints and Martyrs, "Medical History" 1991, No. 35, s. 145-163.

35 Na temat kolekcjonowania relikwii i znaczenia tych kolekcji vide D. Bethell, The Making of a Twelfth-Century Relic Collection, "Studies in Church History" 1972, 
i wino w Eucharystii, relikwie faktycznie symbolizowały fizyczną obecność zmarłego świętego ${ }^{36}$.

Popularność religijnego uzdrawiania, która pochodzi jeszcze z czasów starożytnych, podobnie jak naukę medycyny, można tłumaczyć brakiem fachowej pomocy, w myśl dzisiejszych standardów oraz innym spojrzeniem na życie i śmierć niż mamy obecnie. Granica między żywymi a umarłymi w średniowieczu była trudna do ustalenia. Jeden z kronikarzy zauważył, że ożywienie martwych po kilku dniach nie było niczym niezwykłym w Anglii, ale po siedmiu dniach było wielkim zaskoczeniem ${ }^{37}$. To, co wydawało się cudownym uzdrowieniem w średniowieczu, w rezultacie mogło być całkiem przyziemne i przewidywalne dla medyka. Mnogość takich uzdrowień często powodowała, że ludzie woleli udać się do sanktuarium niż do osoby, która faktycznie znała się na medycynie. Mimo tego, za sprawą tekstów, szpitali czy poetów, powstał ideał średniowiecznego medyka jako kapłana i doradcy. Ten ówczesny medyk mógł być praktykiem medycyny, duchownym bądź też „rzemieślnikiem”. Użycie tego słowa nie jest przypadkowe, ponieważ ludzie praktykujący medycynę traktowali ją właśnie jako rodzaj rzemiosła. Sprzedawali medykamenty i swoje usługi jako członkowie gildii lub będąc na usługach miast. Niekiedy pracowali także dla zakonów lub bogatych domów. Często pobierali wynagrodzenie pieniężne, jednak zdarzało się, że dostawali w zamian jedzenie lub odzie $\dot{z}^{38}$. Z kolei duchowni medycy nie pobierali opłat, a pomaganie innym traktowali jako rodzaj charytatywnego obowiązku, co sprawiło, że chętnie korzystano z ich usług.

No. 8, s. 61-72; idem, The Miracles of St. Ithamar, "Analecta Bollandiana" 1979, No. 89, s. 421-437, gdzie opisuje fortunę, którą biskup anglosaski zbił na relikwiach.

36 Na temat obecności osoby w relikwiach vide K. Park, The Life of the Corpse: Division and Dissection in Late Medieval Europe, "Journal of the History of Medicine" 1995, No. 50, s. 119.

37 R. C. Finucane, Use and Abuse of Medieval Miracles, "History" 1975, No. 60, s. 7.

38 C. Rawcliffe, The Profits of Practice: The Wealth and Status of Medical Men in Later Medieval England, "Social History of Medicine" 1988, No. 1, s. 61-78; E. A. Hammond, Incomes of Medieval English Doctors, "Journal of the History of Medicine" 1960, No. 15, s. 154-169. 


\section{Bibliografia}

BACON R., Epistola de secretis operibus artis et naturae, tłum. B. Orłowski, [w:] Wielcy i mali twórcy cywilizacji, red. L. Sprague De Camp, Warszawa 1968.

BASSETT S., Death in towns: urban responses to the dying and the dead 1001600, Leicester 1993.

BETHELL D., The Making of a Twelfth-Century Relic Collection, "Studies in Church History" 1972, No. 8, s. 61-72.

BETHELL D., The Miracles of St. Ithamar, "Analecta Bollandiana” 1979, No. 89, s. 421-437.

BOLLANDUS I., Acta Sanctorum: Junii I, Antwerp 1695, s. 728-742.

BYLEBYL J. J., Medicine, Philosophy, and Humanism in Renaissance Italy, [w:] Science and the Arts in the Renaissance, eds. J. W. Shirley, F. D. Hoeniger, Washington 1985, s. 27-49.

CAMERON M. L., Anglo-Saxon Medicine, [w:] Cambridge Studies in Anglo-Saxon England 7, Cambridge 1993.

CARLIN M., Medieval English Hospitals, [w:] The Hospital in History, eds. L. Granshaw, R. Porter, London 1989.

CLARK E., Some Aspects of Social Security in Medieval England, "Journal of Family History" 1982, No. 7, s. 307-320.

CLAY M. R., The medieval hospitals of England, London 1909.

COCKAYNE O., Leechdoms, Wortcunning, and Starcraft of Early England, t. 2, London 1864.

FARMER D. H., The Oxford Dictionary of Saints, Oxford 1978.

FINUCANE R. C., Use and Abuse of Medieval Miracles, "History" 1975, No. 60, s. 1-10.

GIOCARINIS K., KAY R., The Medieval Heritage of a Humanistic Ideal: "Scientia Donum Dei Est, unde Vendi Non Potest", “Traditio” 1955, No. 11, s. 195-234.

GORDON E., Accidents among Medieval Children as Seen from the Miracles of Six English Saints and Martyrs, "Medical History" 1991, No. 35, s. 145-163.

GORDON E., Child Health in the Middle Ages as Seen in the Miracles of Five English Saints, A.D. 1150-1220, "Bulletin of the History of Medicine" 1986, No. 60, s. 502-522.

HAMMOND E. A., Incomes of Medieval English Doctors, "Journal of the History of Medicine" 1960, No. 15, s. 154-169.

KOFF L. M., Chaucer and the Art of Storytelling, California 1988.

LEVINE J. M., Humanism and History: Origins of Modern English Historiography, New York 1987.

MARCOMBE D., Leper Knights. The Order of St Lazarus of Jerusalem in England, c. 1150-1544, Woodbridge 2003. 
MARSH F. T., Annals of the Hospital of S. Wulstan, or the commandery in the city of Worcester; together with a chartulary of the said hospital, Worcester 1890, s. 111-114.

NAUERT Ch. G., Humanism and the Culture of Renaissance Europe, Cambridge 1995.

ORME N., WEBSTER M., The English Hospital 1070-1570, New Haven 1995.

PARK K., The Life of the Corpse: Division and Dissection in Late Medieval Europe, "Journal of the History of Medicine" 1995, No. 50, s. 111-132.

RATHER L. J., The Six Things Non-Natural: A Note on the Origins and Fate of a Doctrine and a Phrase, "Clio Medica" 1968, No. 3, s. 337-347.

RAWCLIFFE C., The Hospitals of Later Medieval London, "Medical History" 1984, No. 28, s. 1-12.

RAWCLIFFE C., The Profits of Practice: The Wealth and Status of Medical Men in Later Medieval England, "Social History of Medicine" 1988, No. 1, s. 6178.

REYNOLDS L. D., WILSON N. G., Scribes and Scholars: A Guide to the Transmission of Greek and Latin Literature, Oxford 1974.

RIGG A. G., The Latin Verses in the Confessio Amantis: An Annotated Translation, eds. S. Echard, C. Fanger, East Lassing 1991.

RUBIN S., The Monastic Infirmary, [w:] Medieval English Medicine, New York 1974, s. 172-188.

SCOTT R. N., The several compilers of Bald's Leechbook, "Anglo-Saxon England" 2004, No. 33, s. 51-76.

SHAHAR S., Who Were Old in the Middle Ages, "Social History of Medicine" 1993, No. 6, s. 313-341.

SOUTHERN R. W., Scholastic Humanism and the Unification of Europe, Oxford 1995, s. 17-57.

SWEET H., First Middle English Primer, Pennsylvania 2005.

WEISS R., Humanism in England during the Fifteenth Century, Oxford 1957.

The Works of Geoffrey Chaucer, ed. F. N. Robinson, Boston 1957. 